\title{
A microRNA-related single nucleotide polymorphism of the XPO5 gene is associated with survival of small cell lung cancer patients
}

\author{
ZHANJUN GUO ${ }^{1}$, HONGJING WANG ${ }^{2}$, YANTAO LI $^{2}$, BIN LI $^{2},{\mathrm{CUIQIAO} \mathrm{LI}^{2} \text { and CUIMIN DING }}^{2}$ \\ Departments of ${ }^{1}$ Gastroenterology and Hepatology and ${ }^{2}$ Respiratory Medicine, \\ The Fourth Hospital of Hebei Medical University, Shijiazhuang, Hebei 050011, P.R. China
}

Received February 1, 2013; Accepted March 20, 2013

DOI: $10.3892 /$ br.2013.92

\begin{abstract}
MicroRNA (miRNA)-related single nucleotide polymorphisms (miR-SNPs) in miRNA processing machinery genes affect cancer risk, treatment efficacy and patient prognosis. A miR-SNP of rs11077 located in the 3'UTR of miRNA processing machinery gene XPO5 was examined in small cell lung cancer (SCLC) patients to evaluate its association with cancer survival. A total of 42 patients were enrolled in the present study and genotyped for rs11077 and survival was assessed using the Kaplan-Meier method, as well as univariate and multivariate analyses. The AA genotype of rs11077 was identified for its significant association with better survival time $(\mathrm{P}=0.023)$. In addition, rs11077 was found to associate independently with overall survival in SCLC patients by multivariate analysis (relative risk 2.469; 95\% CI, 1.088-5.603; $\mathrm{P}=0.031$ ). The findings of this study suggest that although miR-SNP studies for miRNA processing machinery genes are still at an early age, miR-SNPs have an impact on cancer survival. In conclusion, a miR-SNP in the 3'UTR region of the XPO5 gene was identified as an independent prognostic marker for survival of advanced SCLC patients.
\end{abstract}

\section{Introduction}

Small cell lung cancer (SCLC), commonly classified by the Veterans Administration Lung Cancer Study Group as Limited stage and Extensive stage groups, constitutes $\sim 15 \%$ of all lung cancer cases and is strongly associated with cigarette smoking (1-3). The prognosis of SCLC, which has been associated with extent of disease and other factors, is poor, whereas the life expectancy of those with untreated SCLC is

Correspondence to: Dr Cuimin Ding, Department of Respiratory Medicine, The Fourth Hospital of Hebei Medical University, 12 Jiankang Road, Shijiazhuang, Hebei 050011, P.R. China

E-mail:wjwdem@sina.com

Key words: small cell lung cancer, miR-SNP, survival, exportin-5, rs11077 $\sim 3.5$ months for the limited stage group and 6 weeks for the extensive stage group (4-6). Although genetic factors have been identified as prognostic factors for SCLC, the underlying mechanism of this cancer remains unknown (7-9).

MicroRNAs (miRNAs) are RNA molecules that are $\sim 22$ nucleotides long and are involved in various biological processes, such as embryonic development, cell differentiation, proliferation, apoptosis, cancer development and insulin secretion $(10,11)$. More than 700 miRNAs have been identified in humans and these miRNAs are responsible for regulating at least $30 \%$ of protein-coding gene expressions (12). A growing body of evidence suggests that miRNAs play important roles in a broad range of biological processes, as previously mentioned (9-11). In the miRNA processing, long primary transcripts of miRNAs (pri-miRNAs) are processed in the nucleus by RNase III Drosha and transported to the cytoplasm by the nuclear transport factor exportin-5 (XPO5) and RAN. In the cytoplasm, RNase III Dicer and transactivation-responsive RNA-binding protein (TRBP) mediate the processing of pre-miRNAs in order to release a 21-bp dsRNA. Additionally, the RNA-induced silencing complex (RISC) including GEMIN3 and GEMIN4 selects a single strand as the mature miRNA and guides the mature miRNAs to their target mRNA sites (10,13-16). miRNA-related single nucleotide polymorphisms (miR-SNPs), defined as SNPs in miRNA genes, miRNA binding site and miRNA processing machinery, are able to modulate miRNA and target gene expressions in order to influence cancer risk, treatment efficacy and patient prognosis $(9,17-20)$.

A miR-SNP of rs11077 located in the 3'UTR of the miRNA processing gene XPO5 has shown its association with the chemotherapeutic response in metastatic colon cancer as well as recurrence in resected non-small cell lung cancer (NSCLC) $(9,19)$. In the present study, we evaluated the predictive power of this SNP on the overall survival of SCLC patients.

\section{Materials and methods}

Tissue specimens and DNA extraction. Blood samples were collected at the Fourth Hospital of Hebei University from 42 SCLC patients who received treatment in the Department 
Table I. Univariate and multivariate analysis of clinical factors associated with small cell lung cancer survival.

\begin{tabular}{|c|c|c|c|c|c|c|}
\hline \multirow[b]{2}{*}{ Factors } & \multirow[b]{2}{*}{ No. of cases } & \multirow{2}{*}{$\begin{array}{c}\text { 2-year survival } \\
\text { rate }(\%)\end{array}$} & \multirow{2}{*}{$\frac{\text { Univariate analysis }}{\text { P-value }}$} & \multicolumn{3}{|c|}{ Multivariate analysis } \\
\hline & & & & RR & $95 \% \mathrm{CI}$ & P-value \\
\hline Age (years) & & & 0.122 & 1.269 & $0.611-2.634$ & 0.523 \\
\hline$\leq 60$ & 26 & 26.9 & & & & \\
\hline$>60$ & 16 & 18.8 & & & & \\
\hline Gender & & & 0.113 & 0.167 & $0.047-0.588$ & 0.005 \\
\hline Male & 28 & 14.3 & & & & \\
\hline Female & 14 & 42.9 & & & & \\
\hline VALSG classification & & & 0.229 & 1.410 & $0.691-2.876$ & 0.345 \\
\hline Limited & 19 & 26.3 & & & & \\
\hline Extensive & 23 & 21.7 & & & & \\
\hline Smoking & & & 0.771 & 3.581 & $1.110-11.555$ & 0.033 \\
\hline Yes & 23 & 17.4 & & & & \\
\hline No & 19 & 31.6 & & & & \\
\hline Treatment & & & 0.506 & 1.037 & $0.519-2.072$ & 0.919 \\
\hline Chemotherapy & 18 & 22.2 & & & & \\
\hline Combination & 24 & 25.0 & & & & \\
\hline Genotype & & & 0.023 & 2.469 & $1.088-5.603$ & 0.031 \\
\hline AA & 33 & 27.3 & & & & \\
\hline $\mathrm{AC}+\mathrm{CC}$ & 9 & 11.1 & & & & \\
\hline
\end{tabular}

RR, response rate; VALSG, Veteran Administration Lung Cancer Study Group; combination, chemotherapy combined with radiotherapy.

of Respiratory Medicine between 2005 and 2009. The genomic DNA was immediately extracted using the Wizard Genomic DNA extraction kit (Promega, Madison, WI, USA) and stored at $-20^{\circ} \mathrm{C}$. The procedures were supervised and approved by the Human Tissue Research Committee at the hospital and informed consent was obtained from all 42 participants.

Genotyping of miR-SNPs. The miR-SNP rs11077 of the miRNA processing genes XPO5 was genotyped using the LDR method with the primers: forward: 5'-GAATCTGG TCACCTGATGGGA-3' and reverse: 5'-GTGCCTGAGTG GACCTTGAG-3', in order to amplify the DNA fragments flanking miR-SNPs based on the NCBI SNP database (http:// www.ncbi.nlm.nih.gov/snp/). PCR was performed using a PCR master mix kit according to the manufacturer's instructions (Promega). The ligation was performed using the different probes: S1: 5'-GTACCTCCAAGGACCAGGGCTGGGA-3' or S2: 5'-TTTGTACCTCCAAGGACCAGGGCTGGGC-3' matched to the alleles of miR-SNPs. The S1 or S2 probe was ligated with S3: 5'-AGTCTTTAGTGCTAACATCCCCTTT-3' downstream of the SNP site, and the ligated products were separated using the ABI Prism Genetic Analyzer 3730xl (Applied Biosystems, Foster City, CA, USA). Polymorphisms were confirmed based on a 3 bp length difference of ligated products.

Statistical analysis. Survival curves were calculated using the Kaplan-Meier method, and comparisons between the curves

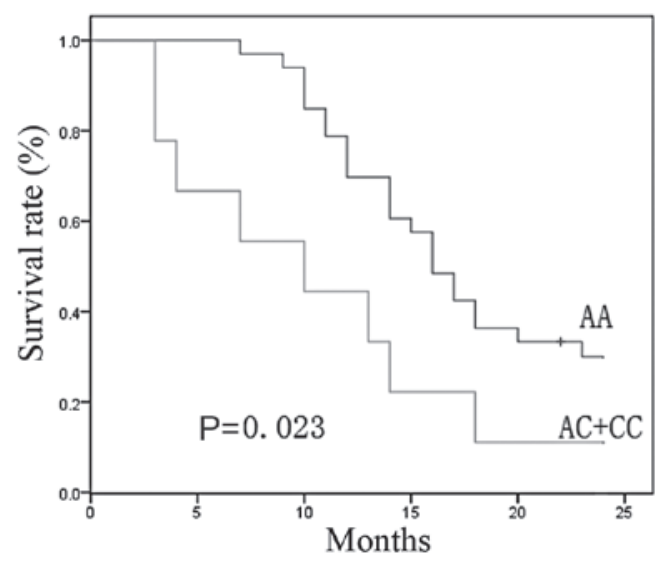

Figure 1. Genotype of rs11077 and its association with small cell lung cancer survival.

were made using the log-rank test. Multivariate survival analysis was performed using a Cox proportional hazards model. The statistical analyses were performed using the SPSS 18.0 software package (SPSS, Inc., Chicago, IL, USA). P<0.05 was considered to indicate a statistically significant difference.

\section{Results}

Analysis of clinical characteristics with overall survival. A total of 42 patients enrolled in this study were reviewed every 3 months for 2 years. The associations between two-year 
survival data and clinical characteristics were compared by the univariate and multivariate analysis in SCLC patients. Age and smoking status were identified as independent predictors for SCLC survival using the Cox proportional hazards model (Table I).

Association of rs 11077 with outcome of SCLC. In total, 42 SCLC patients were genotyped for rs11077. The rs11077 $\mathrm{CC}, \mathrm{AC}$ and AA genotype frequencies were 1, 8 and 33, respectively. The SCLC patients were divided into two groups on the basis of their rs11077 genotype, and their overall survival curves were plotted using the Kaplan-Meier method. The two-year survival rate of $\mathrm{AC}+\mathrm{CC}$ and $\mathrm{AA}$ patients were 11.1 and $27.3 \%$. A significant difference in overall survival was observed between the two groups (Fig. 1). Patients with the AA allele were associated with a significantly longer survival time compared with that of $\mathrm{AC}+\mathrm{CC}$ patients $(\mathrm{P}=0.023)$.

A multivariate analysis with the Cox proportional hazards model for clinical characteristics was performed. As shown in Table I, the rs11077 SNP was identified as an independent predictor for the overall survival of SCLC patients (relative risk 2.649; 95\% CI, 1.088-5.603; $\mathrm{P}=0.031$ ).

\section{Discussion}

The identification of predictive markers for tumor outcome is a new field in cancer research. Investigations to determine whether miRNA expression is associated with tumors has attracted attention. The altered expression of a number of miRNAs has been found to predict anticancer treatments (22). In previous reports (19), rs11077 has been identified to be associated with recurrence in post-operative NSCLC patients. In the present study, we report that the miR-SNP in miRNA processing machinery genes of XPO5 are involved in the prognosis of SCLC outcome.

XPO5 is found in the nuclear membrane and mediates the transport of pre-miRNA in order to adjust the miRNA expression (23). XPO5 inactivation resulted in reduced miRNA processing and decreased miRNA target inhibition, while the restored XPO5 reverses the impaired export of pre-miRNA (24). The miR-SNP of rs11077 of XPO5 has been identified for its association with the cancer risk of esophageal cancer as well as the outcome of myeloma $(20,25)$. The mechanism of how this SNP affects SCLC survival remains unclear. This finding suggests that SNP located in 3'UTR of $X P O 5$ may affect mRNA stability and is associated with an altered expression of XPO5. The altered XPO5 expression may affect the expression of miRNAs, resulting in SCLC survival.

Although miR-SNP studies for miRNA processing machinery genes are at an early stage, our results are encouraging, as they indicate that miR-SNPs affect cancer survival. However, the results from this study require validation in other populations and in laboratory-based functional studies. MicroRNAs have been emphasized as a key factor in the susceptibility of patietns to the therapeutic response in many complex diseases, including cancer (26). In conclusion, a miR-SNP in the 3'UTR region of XPO5 was found to be an independent prognostic marker for survival of advanced SCLC patients.

\section{References}

1. Adjei AA, Marks RS and Bonner JA: Current guidelines for the management of small cell lung cancer. Mayo Clin Proc 74: 809-816, 1999.

2. Simon GR and Wagner H: American College of Chest Physicians. Small cell lung cancer. Chest 123 (Supp 1): 259S-271S, 2003.

3. National Comprehensive Cancer Network. National Comprehensive Cancer Network practice guidelines in oncology v. 1.2007: small cell lung cancer. Available at: http://www.nccn. org/professionals/physician_gls/PDF/sclc.pdf. Accessed January 9, 2007.

4. Hyde L, Yee J, Wilson R and Panto ME: Cell type and the natural history of lung cancer. JAMA 193: 52-54, 1965

5. Lassen U, Osterlind K, Hansen M, Dombernowsky P, Bergman B and Hansen HH: Longterm survival in small-cell lung cancer: posttreatment characteristics in patients surviving 5 to $18+$ years - an analysis of 1,714 consecutive patients. J Clin Oncol 13: 1215-1220, 1995.

6. Rawson NS and Peto J: An overview of prognostic factors in small cell lung cancer. A report from the Subcommittee for the Management of Lung Cancer of the United Kingdom Coordinating Committee on Cancer Research. Br J Cancer 61: 597-604, 1990.

7. Knez L, Sodja E, Kern I, Košnik M and Cufer T: Predictive value of multidrug resistance protein, topoisomerases II and ERCC1 in small cell lung cancer: a systematic review. Lung Cancer 72: 271-279, 2011.

8. Kin YH, Ishii G, Goto K, Ota S, Kubota K, Murata Y, Mishima M, Saijo N, Nishiwaki Y and Ochiai A: Expression of the breast cancer resistance protein is associated with a poor clinical outcome in patients with small-cell lung cancer. Lung Cancer 65: 105-111, 2009.

9. Ding C, Li R, Peng J, Li S and Guo Z: A polymorphism at the miR-502 binding site in the 3' untranslated region of the SET8 gene is associated with the outcome of small-cell lung cancer. Exp Ther Med 3: 689-692, 2012.

10. Bartel DP: MicroRNAs: genomics, biogenesis, mechanism, and function. Cell 116: 281-297, 2004.

11. Ambros V: The functions of animal microRNAs. Nature 431: 350-355, 2004.

12. Lewis BP, Burge CB and Bartel DP: Conserved seed pairing, often flanked by adenosines, indicates that thousands of human genes are microRNA targets. Cell 120: 15-20, 2005.

13. Cullen BR: Transcription and processing of human microRNA precursors. Mol Cell 16: 861-865, 2004

14. Lee Y, Ahn C, Han J, Choi H, Kim J, Yim J, Lee J, Provost P, Rådmark O, Kim S and Kim VN: The nuclear RNase III Drosha initiates microRNA processing. Nature 425: 415-419, 2003.

15. Yi R, Qin Y, Macara IG and Cullen BR: Exportin-5 mediates the nuclear export of pre-microRNAs and short hairpin RNAs. Genes Dev 17: 3011-3016, 2003

16. Chendrimada TP, Gregory RI, Kumaraswamy E, Norman J, Cooch N, Nishikura K and Shiekhattar R: TRBP recruits the Dicer complex to Ago2 for microRNA processing and gene silencing. Nature 436: 740-744, 2005

17. Ryan BM, Robles AI and Harris CC: Genetic variation in microRNA networks: the implications for cancer research. Nat Rev Cancer 10: 389-402, 2010.

18. Guo Z, Wu C, Wang X, Wang C, Zhang R and Shan B: A polymorphism at the miR-502 binding site in the 3'-untranslated region of the histone methyltransferase SET8 is associated with hepatocellular carcinoma outcome. Int J Cancer 131: 1318-1322, 2012.

19. Campayo M, Navarro A, Viñolas N, Tejero R, Muñoz C, Diaz T, Marrades R, Cabanas ML, Gimferrer JM, Gascon P, Ramirez J and Monzo M: A dual role for KRT81: a miR-SNP associated with recurrence in non-small-cell lung cancer and a novel marker of squamous cell lung carcinoma. PLoS One 6: e22509, 2011.

20. de Larrea CF, Navarro A, Tejero R, Tovar N, Díaz T, Cibeira MT, Rosiñol L, Ferrer G, Rovira M, Rozman M, Monzó M and Bladé J: Impact of MiRSNPs on survival and progression in patients with multiple myeloma undergoing autologous stem cell transplantation. Clin Cancer Res 18: 3697-3704, 2012.

21. Therasse P, Arbuck SG, Eisenhauer EA, Wanders J, Kaplan RS, Rubinstein L, Verweij J, Van Glabbeke M, van Oosterom AT, Christian MC and Gwyther SG: New guidelines to evaluate the response to treatment in solid tumors. European Organization for Research and Treatment of Cancer, National Cancer Institute of the United States, National Cancer Institute of Canada. J Natl Cancer Inst 92: 205-216, 2000. 
22. Hummel R, Hussey DJ and Haier J: MicroRNAs: predictors and modifiers of chemo- and radiotherapy in different tumour types. Eur J Cancer 46: 298-311, 2010.

23. Lund E, Güttinger S, Calado A, Dahlberg JE and Kutay U: Nuclear export of microRNA precursors. Science 303: 95-98, 2004.

24. Melo SA, Moutinho C, Ropero S, Calin GA, Rossi S, Spizzo R, Fernandez AF, Davalos V, Villanueva A, Montoya G, Yamamoto H, Schwartz S Jr and Esteller M: A genetic defect in exportin-5 traps precursor microRNAs in the nucleus of cancer cells. Cancer Cell 18: 303-315, 2010.
25. Ye Y, Wang KK, Gu J, Yang H, Lin J, Ajani JA and Wu X: Genetic variations in microRNA-related genes are novel susceptibility loci for esophageal cancer risk. Cancer Prev Res (Phila) 1: 460-469, 2008.

26. Iorio MV, Ferracin M, Liu CG, Veronese A, Spizzo R, Sabbioni S, Magri E, Pedriali M, Fabbri M, Campiglio M, Ménard S, Palazzo JP, Rosenberg A, Musiani P, Volinia S, Nenci I, Calin GA, Querzoli P, Negrini M and Croce CM: MicroRNA gene expression deregulation in human breast cancer. Cancer Res 65: 7065-7070,2005. 